AperTO - Archivio Istituzionale Open Access dell'Università di Torino

\title{
Eosinophilic colitis: clinical review and 2020 update
}

\section{This is the author's manuscript}

Original Citation:

Availability:

This version is available http://hdl.handle.net/2318/1741897

since 2020-07-11T09:43:49Z

Published version:

DOI:10.23736/S1121-421X.20.02656-2

Terms of use:

Open Access

Anyone can freely access the full text of works made available as "Open Access". Works made available under a Creative Commons license can be used according to the terms and conditions of said license. Use of all other works requires consent of the right holder (author or publisher) if not exempted from copyright protection by the applicable law. 


\section{Eosinophilic Colitis: clinical review and update 2020}

Journal: Minerva Gastroenterologica e Dietologica

Paper code: Minerva Gastroenterol Dietol-2656

Submission date: December 4, 2019

Article type: Review Article

Files:

1. Manuscript

Version: 1

Description: Manoscritto originale

File format: application/msword

2. Figures 1

Version: 1

Description: Figura 1

File format: application/pdf 


\section{Gabriele GIUDICI' ${ }^{1}$, Davide Giuseppe RIBALDONE², Marco ASTEGIANOª, Giorgio Maria} SARACCO $^{1,3}$, Rinaldo PELLICANO ${ }^{3}$

${ }^{1}$ Chair of Gastroenterology, Department of Medical Sciences, University of Turin, Twine, Italy;

${ }^{2}$ Department of Surgical Sciences, University of Turin, Turim, Italy;

${ }^{3}$ Unit of Gastroenterology, Molinette-SGAS Hospital, Turin, Italy:

*Corresponding author: Rinaldo Pelícano, Unitof Gastroenterology, Molinette-SGAS Hospital, Via Cavour 31, 10126 Turin Italy.

E-mail: rinaldo_pellican@ hotmail.com 


\begin{abstract}
Eosinophilic colitis (EC) is a rare inflammatory disease included in the chapter of eosinophilic gastrointestinal disorders (EGIDs), diagnosed by the presence of primary eosinophilic infiltrate in the colon wall in symptomatic patients. While the aetiology of primary colonic eosinophilia is unknown, several conditions are involved in the pathogenesis of secondary eosinophilic colonic infiltrate (food allergens, parasitic infections, drugs), which have to be excluded worder to correctly diagnose the primary form of the disease. Up to now, EC is lacking of codified guidelines regarding diagnostic criteria (especially eosinophil threshold values) and treatment, thas acomect approach to EC remains very challenging. Imaging, laboratory tests and endoscopy might be helpful in ruling out other mimic conditions, but EC is still a diagnosis of exclusion. Several treatment options are feasible, but most of the evidences are dirawif from case reports and small case series, thus limiting their value. We carried out a review of the current literature to evaluate the more appropriate and modern clinical strategy for diagnosis and rnanagement of EC.
\end{abstract}




\section{Introduction}

Eosinophilic colitis (EC) is a rare inflammatory disease, included in the chapter of eosinophilic gastrointestinal disorders (EGIDs), and characterized by a high eosinophilic infiltrate in the colonic wall, with unknown causes. ${ }^{1,2,48,56}$ The definition of EC is still disputed. On the basis of the recent international literature, the term "eosinophilic colitis" should be reserved to symptomatic patients, whereas asymptomatic patients with a significant increase in colonic eosinophils should receive a diagnosis of "primary colonic eosinophilia" (PCE). ${ }^{3}$ Nevertheless, PCE remains a poorly characterized condition, even less than EC itself, that pathologists may-eonsider when "greater than normal" numbers of eosinophils are found in colonic mucosa. ${ }^{2}$ For EC, there are no clear threshold values for eosinophils at this moment; matter of fact, even the normal number of eosinophils in colonic mucosa has not been clearly defined yet. ${ }^{34}$

In this narrative review we report the updated evidence from literature, so to deeply examine etiology, pathophysiology, diagnostic criteria and therapeutic strategies of this condition.

\section{Epidemiology}

Primary eosinophilic colitis is considered to be a rare disease. Since there are no standardized diagnostic criteria, it is unclear therealtrequency in the general population. ${ }^{1,5}$ A US database review performed on about 35 million people reported a prevalence of 2,1/100,000 persons. EC seems to be inore common in adults $(2,3 / 100000)$ than in children $(1,6 / 100000)$ with a slightly higher ratio in women and in caucasian individuals. ${ }^{5}$ Other studies seem to show a bimodal age distribution, firstly in neonates and secondly in adulthood. ${ }^{6,7}$ It is known that EC, such as other EGIDs, is more common in urban and suburban areas versus rural areas and in patients with a higher level of education. ${ }^{8}$ It has been shown that EC is associated with a wide spectrum of allergic disorders, such as drug allergy, rhinitis, asthma, sinusitis, dermatitis, food allergy, eczema, and urticaria. $^{5}$ 


\section{Pathophisiology}

Today all the physiologic functions of eosinophils are still not completely known, ${ }^{10}$ making the pathogenesis of EC poorly understood. ${ }^{4}$ Eosinophils are by far more common in tissue than in blood and in the GI tract usually reside in the lamina propria of the small intestine, except the squamous epithelium of the esophagus. ${ }^{11}$ They are involved in several functions, especially in protection against bacterial and parasites, regulation of the intestinal microbiome and tissue homoeostasis Eosinophils are activated by several stimuli including allergens, bacterial and parasites ififections and they are regulated by variety of cytokines, such as interleukin (IL)-5, $\mathrm{L}-13, \mathrm{IF}-4$ and tumor necrosis factor (TNF), mostly produced by activated Th2 T-1ymphocytes and mast cells. ${ }^{12,13}$ Once activated, eosinophils release cytotoxic proteins, Leukotriene C4 (LTC4) and several other cytokines that modulate the immune system by activating dendritic cells, inducing immunoglobulin (Ig)A-class switching in B cells and promoting their survival. It is general thought that several factors such as genetic predisposition, dysbiosis, and tagenvironment (i.e. allergens) play a pivotal role in EGIDs, but the clear understanding of their) relationship is still unknown. ${ }^{4}$ EC pathophysiology is related to age of onset. in infants, it seems to be an IgE-associated disorder since it has been reported in association with breast-feeding protein hydrolysate formula-feeding. Instead, in adults it is more likely due toa $\mathrm{Th} 2 \mathrm{~T}$-lymphocyte driven response. ${ }^{1}$ Studies have found association with autoimrmune disorders such as inflammatory bowel diseases (IBD), ${ }^{14}$ celiac disease, ${ }^{15}$ rheumatord arthritis, systemic lupus erythematosus, systemic sclerosis and inflammatory myositis. ${ }^{16,17}$ This suggest a possible role of allergen-related immune dysregulation. ${ }^{18}$

\section{Clinical features}

The clinical presentation of EC is heterogeneous and usually non-specific. An acute presentation is more common in infants as a self-limited bloody diarrhea, whereas the chronic presentation is more 
common in adults and it is usually associated with abdominal pain and/or chronic watery diarrhea. ${ }^{1}$ Several other symptoms are commonly associated with EC, such as heartburn, dysphagia, nausea and vomiting, abdominal pain, unjustified weight loss, ascites, volvulus/intussusception, GI perforation, obstruction or haemorrhage. ${ }^{5}$ Since EC is frequently associated with history of atopy, other symptoms or diseases might be present, including asthma, food sensitivities, rhinitis or eczema. $^{21,22}$

The eosinophilic infiltration can be located in various layers and depth of bowel wall. Three patterns have been described, that can be simultaneously present in the same patient. ${ }^{19}$ Mucosal disease (Type 1) is the most common and is usually associated with diarrhea, bleeding (which can lead to iron-deficiency anaemia) and protein losing enteropathy Transmura disease (Type 2), much rarer, in which the eosinophilic infiltrations is widespread along the wall and usually associated with wall thickening and/or strictures that can lead to GI obstructions, volvulus and perforations. ${ }^{21}$ Subserosal disease (Type 3) is limited to external part of the bowel wall and is usually associated with eosinophilic ascites and/or bloating.

Type 1 EC clinical course is typically continuow defined by chronic persistent GI symptoms for more than 6 months, without period of remission. Type 2 EC is associated with recurring course, defined by at least 2 lares of the disease, separated by a period without digestive symptoms. Type 3 EC is the most benign since it 18 usually associated to a single flare, defined by clinical symptoms present for $\leq 6$ months as saguated with the absence of any relapse after initial flare. ${ }^{23} \mathrm{EC}$ in infants is mostly benign, sinde it is widely associated with food-related allergy and the elimination of the allergen is enough to resolve the disease within few days. In adolescent or older onset, the course tends to be more aggressive and requires more advanced medical management. ${ }^{1}$ 


\section{Diagnosis}

Since EC is part of EGIDs, diagnosis of EC should match the same criteria, namely: (1) presence of GI symptoms; (2) histologic evidence of eosinophilic infiltration; and (3) ruling out other causes of tissue eosinophilia (Secondary EC). ${ }^{23}$

Laboratory findings might be helpful to suspect EC along the clinic, but typically they are not adequate for EC diagnosis alone. Peripheral eosinophilia (defined as an absclute count of > 500 eosinophils/ $\mu \mathrm{L}$ ) can be present up to $80 \%$ of patients. ${ }^{24}$ Moreover, Type 3 EC is more frequenily associated to hypereosinophilia and is also considered as risk factor for frequent crelapse phenotype. ${ }^{22}$ As in EGIDs, an increase in serum IgE is common in about $75 \%$ of cases. ${ }^{25}$ Since EC has a strong correlation with IgE-mediated pathological responses, allergic skin testing (AST) and radioallergosorbent tests (RAST) might be useful in allergic-EC forms (both ingested or inhaled allergens), although AST shows a high false-positive rate (i.e. lgw specificity) and low sensitivity. ${ }^{1}$ Non-IgE Th2 dependent allergy tests (skin patch) might be more useful in adolescent and adults, although show similar limitations as RAST and AST. ${ }^{2}$ thaecal calprotectin is a reliable non-invasive tool to assess intestinal inflammation, ${ }^{37}$ but has ghown no help in diagnosing EC since its value is usually within the normal 1imit range. 3ris might be related specifically to the inflammatory infiltrate type, peor in neutrophils, whese cytosol contains calprotectin. ${ }^{39,40}$

Radiology and imaging studiemight be helpful, although findings are usually not specific both in children and adults. EC ragiological findings are nodularity of the wall, colonic wall thickening (usually circumferential and located from ascending to the descending colon), "halo sign" (due to layering of the bowel wall) and "araneid-limb-like". This latter sign is usually located in ascending and transverse colon and it is due to contrast enhancement of mucosal sinuses in the longitudinal section of the bowel on computed tomography (CT) scans, enlarged from mucosal thickening. ${ }^{32,43}$ 
Endoscopic appearance of EC is variable and, in most cases, similarly to microscopic colitis shows normal mucosa ${ }^{57}$ several non-specific endoscopic findings might be present, such as erythematous patchy mucosa, ulcers, polyps and pseudo-polyps. ${ }^{3,26}$

Histology is considered the gold-standard, but the clear cut-off for normal eosinophilic counts are not yet defined as well as for other EGIDs such as eosinophilic esophagitis. ${ }^{28,29}$ Because eosinophils are normally present in colonic mucosa of both children and adults and their nurnber depends of several factors, such as age, region, climate, alimentary diet, drugs use and so on. ${ }^{32}$ Several studies have tried to address valid cut-offs, ${ }^{3,30,31}$ and the latest evidence shøws that reasonable cut-ofif might be $>50 /$ high-power field (HPF) in right colon, $>35 / \mathrm{HPF}$ in the transverse colon and $>25 / \mathrm{HPF}$ in the left colon. ${ }^{3} \mathrm{EC}$ is diagnosed with sheets or clusters of eosinophils located in the lamina propria with minimal acute and chronic inflammation. These clusters may show cryptitis degranulation and/or crypt abscesses and might be found also in muscularis mucosa, submucosa or both. ${ }^{27}$ Since the patchy distribution nature of the disease, mutiple endoscopic biopsies are required but, unfortunately, there are no formal guidelines for tistological diagnosis. ${ }^{33}$ Some authors suggest to take at least 5-6 biopsies from beth abnormaland normal endoscopic mucosa in terminal ileum and in each colonic segment, 34, 34, 35 Surgicatbiopsies should be considered the best option, since they provide a full thickness sample iiporder to fully discriminates between the three types of EC, but this is a more invasive proceaure, limited to selected cases. ${ }^{36}$

Once colonic eosinophilianfiltration has been confirmed, it is important to rule out secondary conditions that lead to hypereosinophilia in order to establish a correct diagnosis. The differential diagnosis is wide and includes conditions like parasitic infections (i.e. Strongyloides stercoralis, Schistosoma spp, Trichuris trichiura, Angiostrongylus costaricencis, Gnathostoma spp, Ascaris lumbricoides, Ancylostoma caninum, Ascaris suum, Enterobius vermicularis and Dientamoeba fragilis), drugs (i.e. non-steroidal anti-inflammatory drugs, antiplatelet agents, carbamazepine, clozapine, rifampicin, tacrolimus, enalapril, gemfibrozil, therapeutic gold compound and 
estroprogestinic agents), vasculitis (i.e. Churg-Strauss syndrome, polyarteritis nodosa), connettive tissue diseases (i.e. scleroderma, dermatomyositis, and polymyositis), IBD, celiac disease, myeloproliferative disorders (i.e. hypereosinophilic syndrome) and malignancies (chronic eosinophilic leukaemia, systemic mastocytosis, malignant lymphoma; GI adenocarcinomas might occasionally show a brisk eosinophilic response and EC might be associated with graft-vs-host disease in bone marrow transplanted patients). ${ }^{41}$

A resume of the diagnostic workflow is represented in figure 1.

\section{Treatment}

Since EC is a rare disease, actually there are no strong evidence on available treatments. In fact, most of the evidence are drawn from small uncontrolled case series and case reports. ${ }^{4}$ In general, EC tends to be more aggressive in adolescent and adults, while in infants is rather more benign and usually resolves within days after removing the food-allergen implicated. ${ }^{1}$

Food-eliminating diet (i.e. removal of milk, wheat, soleggs, nuts, and shellfish) is considered the first-line non-pharmacological therapy in EGID邹s but its role seems to be really effective only in children with EC, ${ }^{44}$ whereas there is no clear evidence in adults. ${ }^{26}$ Furthermore, the usefulness of diet is limited by the por compliance in older children and adults. ${ }^{4}$

The use of corticosteryids is considered the first-line pharmacological therapy if dietary approach is impractical or failed to a to inhibit eosinophin growth factors (i.e. IL-3, IL-5 and Granulocyte-macrophage colony-stimulating factor - GM-CSF). ${ }^{33}$ There are no randomized controlled trials to date on the efficacy of steroids in EC. Oral prednisone (20-40 mg per day) for 2 weeks has been shown to induce clinical remission in most patients, ${ }^{45}$ however some reports suggested even the need of higher doses $(0 \cdot 5-1 \mathrm{mg} / \mathrm{kg}) .{ }^{32}$ Maintenance treatment might be required in patients in whom EC relapses during/after drug tapering and low dose systemic corticosteroids are often used (5-10 mg prednisone per day, or the 
minimum dose effective in maintaining clinical response), although possible undesirable long-term side-effects are always to be considered. ${ }^{46}$ Budesonide might be a reasonable alternative, thanks to its low biodisponibility (3-9 $\mathrm{mg}$ per day). ${ }^{47}$

Steroid-spare agents are also a good choice in patients who requires maintenance therapy or fails to respond to corticosteroids. Mesalazine has been used in some cases ${ }^{2}$. Immunomodulatory agents such as azathioprine/6-mercaptopurine or anti-TNF agents (i.e. infliximab, adalimamab) have been tried in severe, steroid-refractory or steroid-dependent EC with good results. ${ }^{48} 49$ Other options might include mast-cell stabilisers (i.e. sodium cromoglycate and ketotifen, 50 and the leukouiene receptor antagonist (montelukast), ${ }^{1}$ although their role in EC has yet to be evaluated.5. 52 A novel antibody directed against C-C chemokine receptor type 3 (CCR 3), an eotaxin receptor expressed by eosinophils that facilitates their recruitment to sites of inflammation, has been shown to decrease eosinophilic inflammation and diarrhea in a mouse model of eosinophilic gastroenteritis. ${ }^{53}$ Since human body harbors between 10 trillion and 100 trillion inicrobial cells (called microbiota), which is approximately equal to 10 times the total nunger of body cells, and considering that the major part is located in GI tract, ${ }^{58}$ it is logical tofry to cure colonic diseases acting on microbiota ${ }^{59}$ and to hypothesize its potential role in several extraintestinal diseases mediated by an impaired permeability. ${ }^{60-66}$ Faecal milerobiotatansplantation has proven efficacy in the treatment of inflammatory diseases of the gm. It has been reported that this treatment, in addition to oral corticosteroids, successfing cured a patient with severe refractory eosinophilic enterocolitis. However, it is unchear whether faecal microbiota transplantation could cure definitively EC and maintain the long-term clinical remission without the use of corticosteroids. ${ }^{54}$ Surgery, performed as segmental colonic resection (without clear evidence if prefer primary anastomosis rather than diversion) should be limited to patients with complications of intestinal inflammation, such as strictures, bowel obstruction or perforation. ${ }^{55}$ Nevertheless, even in the 
setting of an acute abdomen, symptoms might respond to conservative management with immunosuppression. ${ }^{32,50}$

\section{Conclusions}

EC is a rare disease, which still lacks the correct understanding of its pathophysiology and structured guidelines for diagnosis (especially clear cut-off values) and treatment. Unfortunately, there are very few studies which address these needs up to now. Therefore, severar larger casecontrol and cohort studies are required to meet this necessity.

\section{References}

1. Alfadda AA, Storr MA, Shaffer EA. Eosinaphilicc colitis: epidemiology, clinical features, and current management. Therap Adv Gastroenterg1 2011:4:301-9.

2. Alfadda AA, Shaffer EA, Urbanski SJ, Storr MA. Eosinoptilic colitis is a sporadic selflimited disease of middle-aged people: a population-based study. Colorectal Dis 2014;16:123-9.

3. Turner KO, Sinkre RA, Neunann WL, Genta RM. Primary Colonic Eosinophilia and Eosinophilic Colitis in Adults-. Am J (5itrg Pathol 2017;41:225-33.

4. Walker MM,Potter M, Talley NSEsinophilic gastroenteritis and other eosinophilic gut diseases distal to the oesophagur. Lancet Gastroenterol Hepatol 2018;3:271-80.

5. Mansoor E, Saleh MA, Cooper GS. Prevalence of eosinophilic gastroenteritis and colitis in a pepulation-based strady, from 2012 to 2017. Clin Gastroenterol Hepatol 2017;15:1733-41.

6. Collins MH, Capoeelli K, Yang GY. Eosinophilic gastrointestinal disorderspathology. Front Med 2018:4:251.

7. Jensen ET, Martin CF, Kappelman MD, Dellon ES. Prevalence of eosinophilic gastritis, gastroenteritis, and colitis. J Pediatr Gastroenterol Nutr 2016;62:36-42.

8. Chang JY, Choung RS, Lee RM, et al. A shift in the clinical spectrum of eosinophilic gastroenteritis toward the mucosal disease type. Clin Gastroenterol Hepatol 2010;8:669-75.

9. Jung Y, Rothenberg ME. Roles and regulation of gastrointestinal eosinophils in immunity and disease. J Immunol 2014;193:999-1005. 
10. T. Marichal, C. Mesnil and F. Bureau. Homeostatic eosinophils: characteristics and functions. Front Med 2017;4:101.

11. Bochner BS, Klunk DA, Sterbinsky SA, Coffman RL, Schleimer RP. IL-13 selectively induces vascular cell adhesion molecule-1 expression in humanendothelial cells. J Immunol 1995;154:799-803.

12. Bochner BS, Schleimer RP. The role of adhesion molecules in human eosinophiland basophil recruitment. J Allergy Clin Immunol 1994;94:427-38.

13. Copeland BH, Aramide OO, Wehbe SA, Fitzgerald SM, Krishnaswamy G Eosinophilia in a patient with cyclical vomiting: a case report. Clin Mol Allergy 2004,2(1): 7 .

14. Butterfield JH, Murray JA. Eosinophilic gastroenteritis and glutensensitive enteropathy in the same patient. J Clin Gastroenterol 2002;34:552-3.

15. Ciccia F, Giardina AR, Alessi N, Rodolico V, Galia M, Ferrante A, Triolof G. Successful intravenous immunoglobulin treatment for steroid-resistant eosinophicicenteritis in a patient with systemic lupus erythematosus. Clin Exp Rheumatol 2011;29.1018-20.

16. Lecouffe-Desprets M, Groh M, Bour B, Le Ieunne C, Puéchâ. Eosinophilic gastrointestinal disorders associated with autoirnmune connective tissue disease. Joint Bone Spine 2016;83:479-84.

17. Abou Rached A, El Hajj W. Eosinophilic gastroenteritis: Approach to diagnosis and management. World J Gasirøintest Pharmacon Ther 2016;7:513-23.

18. Klein NC, Hargroye L, Sleisenger MH, Peffries GH. Eosinophilic gastroenteritis. Medicine 1970;49:299-319.

19. Kravis LP, South MA, Rosentand ML. Eosinophilic gastroenteritis in the pediatricpatient. Clin Pediatri (Phila) 1982;21:213-7.

20. Talley NJSR, Phillips SE, Zinsmeister AR. Eosinophilic gastroenteritis: a clinicopathologicagstudy of patients with disease of the mucosa, muscle layer, and subserosal 1issues. Gut 1990;31:53.

21. Yun MYCr, Park IS. Eosinophilic gastroenteritis presenting as small bowel obstruction: a case report and review of the literature. World J Gastroenterol 2007;13:1758-60.

22. Pineton de Chambrun G, Gonzalez F, Canva JY, Gonzalez S, Houssin L, Desreumaux P, et al. Natural history of eosinophilic gastroenteritis. Clin Gas-troenterol Hepatol 2011;9:95096.e1.

23. Cello JP. Eosinophilic gastroenteritis--a complex disease entity. Am J Med 1979;67:10971104. 
24. Uppal V, Kreiger P, Kutsch E. Eosinophilic gastroenteritis and colitis: a comprehensive review. Clin Rev Allergy Immunol 2016;50:175-88.

25. Tien FM, Wu JF, Jeng YM, Hsu HY, Ni YH, Chang MH, Lin DT, Chen HL. Clinical features and treatment responses of children with eosinophilic gastroenteritis. Pediatr Neonatol 2011;52:272-8.

26. Okpara N, Aswad B, Baffy G. Eosinophilic colitis. World J Gastroenterol 2009; $15: 2975-9$.

27. Collins MH. Histopathology associated with eosinophilic gastrointestinal diseases. Immunol Allergy Clin North Am 2009;29:109-117.

28. Liacouras CA, Furuta GT, Hirano I, Atkins D, Attwood SE, Bonis PA, Burks AW, Chenade M, Collins MH, Dellon ES, Dohil R, Falk GW, Gonsalves N, Güpta SKK, Katzka DA, Lucendo AJ, Markowitz JE, Noel RJ, Odze RD, Putnam PE, Richter JE, Romero Y, Ruchelli E, Sampson HA, Schoepfer A, Shaheen NJ, Sicherer SH, Spechiegs, Spergel JM, Straumann A, Wershil BK, Rothenberg ME, Aceves SS Eosinophilicesophagitis: updated consensus recommendations for children and adults. JAllergy Clin Immunol 2011;128:320 .

29. Dellon ES1, Jones PD, Martin NB, Kelly M, Kim SC, Freeman KL, Dellon EP, Ferris ME, Shaheen NJ. Health-care transition from pediatric to adult-focused gastroenterology in patients with eosinophilic esophagitis. Dis Esophagus 2013;26: 7-13.

30. Matsushita T1, Maruyama R, Ishikawa N, Harada Y, Araki A, Chen D, Tauchi-Nishi P, Yuki T, Kinoshita Y. The number and distribution of eosinophils in the adult human gastrointestinal tract: a study and comparison of racial and environmental factors. Am J Surg Pathol 2015;39:521-7.

31. Polydorides AD, Banner BE, Hannaway PJ, Yantiss RK. Evaluation of site specific and seasonal variation in colonic mucosal eosinophils. Hum Pathol 2008;39:832-6.

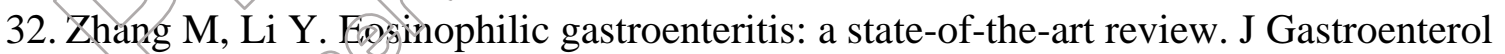
Hepatol 2017, 32:64-7.

33. Impellizzeri G, Marasco G, Eusebi LH, Salfi N, Bazzoli F, Zagari RM. Eosinophilic colitis: A clinical review. Dig Liver Dis 2019;51:769-73.

34. Wong GW, Lim KH, Wan WK, Low SC, Kong SC. Eosinophilic gastroenteritis: clinical profiles and treatment outcomes, a retrospective study of 18 adult patients in a Singapore Tertiary Hospital. Med J Malaysia 2015;70:232-7.

35. North American Society for Pediatric Gastroenterology, Hepatology, and Nutrition; Colitis Foundation of America, Bousvaros A, Antonioli DA, Colletti RB, Dubinsky MC, Glickman 
JN, Gold BD, Griffiths AM, Jevon GP, Higuchi LM, Hyams JS, Kirschner BS, Kugathasan S, Baldassano RN, Russo PA. Differentiating ulcerative colitis from Crohn disease in children and young adults: report of a working group of the North American Society for Pediatric Gastroenterology, Hepatology, and Nutrition and the Crohn's and Colitis Foundation of America. Journal of Pediatric Gastroenterology and Nutrition, 2007 May;44(5):653-74.

36. Solis-Herruzo JA, de Cuenca B, Muñoz-Yagüe MT. Laparoscopic findings in serosal eosinophilic gastroenteritis. Report of two cases. Endoscopy 1988;20:152-3.

37. Caviglia GP, Ribaldone DG, Rosso C, Saracco GM, Astegiano M, Pellicano R. Fecal calprotectin: beyond intestinal organic diseases. Panminerva Med 2018;50:29-34.

38. Bunn SK, Bisset WM, Main MJ, Gray ES, Olson S, Golden BE. Fecal calprotectin: validation as a noninvasive measure of bowel inflammation in childhood . bowel disease. J Pediatr Gastroenterol Nutr 2001;33.14-22.

39. Konikoff MR, Denson LA. Role of fecal calprotectin as a biomarker of intestinal inflammation in inflammatory bowel disease. Inflam Bowel Dis 2006;12:524-34.

40. Leach ST, Day AS. S100 proteins in the pathogenesis andidiagnosis of inflammatory bowel disease," Exp Rev Clin Immungi 2006;2:471-80.

41. Hurrell JM, Genta RM, Melton SD Histopathologic diagnosis of eosinophilic conditions in the gastrointestinal tract. Adr Anat Pathol_2011; 18:335-48.

42. Guajardo JR, Plotnick LM, Fende JM, Colins MH, Putnam PE, Rothenberg ME. Eosinophil-associated gastrointestinal disorders: a world-wide-web based registry. J Pediatr $2002 ; 141: 576-81$.

43. Anuradha 6, Mittal R, Yacob M, Manipadam MT, Kurian S, Eapen A. Eosinophilic disorders of the gastrointestinal tract: imaging features. Diagn Interv Radiol 2012;18:183-8. 44. Lucendo AJ, Serang-Montalban B, Arias A, Redondo O, Tenias JM. Efficacy of dietary treatment for inducing disease remission in eosinophilic gastroenteritis. J Pediatr Gastroenterol Nutr 2015;61:56-64.

45. Lee CM, Changchien CS, Chen PC, Lin DY, Sheen IS, Whang CS, et al. Eosinophilic gastroenteritis: 10 years experience. Am J Gastroenterol 1993;88:70-4.

46. Chen MJ, Chu CH, Lin SC, Shih SC, Wang TE. Eosinophilic gastroenteritis: clinical experience with 15 patients. World J Gastroenterol 2003;9:2813-6. 
47. Siewert E, Lammert F, Koppitz P, Schmidt T, Matern S. Eosinophilic gastroenteritis with severe protein-losing enteropathy: successful treatment with budesonide. Dig Liver Dis 2006;38:55-9.

48. Lucendo AJ. Eosinophilic esophagitis: current evidence-based diagnosis and treatment in children and adults Minerva Gastroenterol Dietol 2018;64:62-74.

49. Al-Haddad S, Riddell RH. The role of eosinophils in inflammatory bowel disease. Gut 2005; 54:1674-5.

50. Gupta N, Aggarwal A, Gupta R, Sule S, Wolf DC. The management of eosinophilic gastroenteritis. Scand J Gastroenterol 2015;50:1309-14.

51. Melamed I, Feanny SJ, Sherman PM, Roifman CM. Benefit of ketotifen in patients with eosinophilic gastroenteritis. Am J Med 1991;90:310-4.

52. Perez-Millàn A, Martin-Lorente JL, Lòpez-Morante A, Yuguero L, Sàez-Bagyuela F. Subserosal eosinophilic gastroenteritis treated efficaciousiy with sodun cromoglycate. Dig Dis Sci 1997;42:342-4.

53. Song DJ, Shim MH, Lee N, Yoo Y, Choung JT. CCR3 moneclonal antibody inhibits eosinophilic inflammation and mucosal injury in a mousermodel of eosinophilic gastroenteritis. Allergy Asthma mimuno1 Res 2017:9:360-67.

54. Dai YX, Shi CB, Cui BT, Wang M, Ji GZ, Zhang FM. Fecal microbiota transplantation and prednisone for severe eosinophilic gastroenteritis. World J Gastroenterol 2014;20:16368-71.

55. Gaertner WB, Macdonald JE, Kwaan MR, Shepela C, Madoff R, Jessurun J, et al. Eosinophilic colitis: university of Minnesota experience and literature review. Gastroenterol Res Pract 2011,2011:857508.

56. Pellicano R. De A.ngelis C, Ribaldone DG, Fagoonee S, Astegiano M. 2013 update on celiac disease and eosinophilice ésophagitis. Nutrients 2013;5:3329-36.

57. Mosso E, Boano \& Grassini M, Battaglia E, Pellicano R Microscopic colitis: a narrative review with Ginical approach. Minerva Gastroenterol Dietol 2019;65:53-62.

58. Fagoonee S, Pellicano R. Does the Microbiota Play a Pivotal Role in the Pathogenesis of Irritable Bowel Syndrome? J Clin Med 2019 Oct 30;8(11).

59. Pellicano R, Ribaldone DG, Astegiano M, Dughera L, Battaglia E, Morgando A, et al. Gastroenterology today: between certainties and news. Minerva Gastroenterol Dietol 2018;64:323-32.

60. Ribaldone DG, Vernero M, Pellicano R. Is microbiome a target for the management of allergy associated diseases in children? Eur Rev Med Pharmacol Sci 2018;22:8061-2. 
61. Masoodi I, Alshanqeeti AS, Ahmad S, Alyamani EJ, Al-Lehibi AA, Qutub AN, et al. Microbial dysbiosis in inflammatory bowel diseases: results of a metagenomic study in Saudi Arabia. Minerva Gastroenterol Dietol 2019;65:177-86.

62. Korotkyi OH, Vovk AA, Dranitsina AS, Falalyeyeva TM, Dvorshchenko KO, Fagoonee S, et al. The influence of probiotic diet and chondroitin sulfate administration on Ptgs2, Tgfb1 and Col2a1 expression in rat knee cartilage during monoiodoacetate-induced osteoarthritis. Minerva Med 2019;110:419-24.

63. Pasini E, Corsetti G, Assanelli D, Testa C, Romano C, Dioguardi FS, et al. Effects of chronic exercise on gut microbiota and intestinal barrier in human with type 2 diabetes. Minerva Med 2019;110:3-11.

64. Abenavoli L, Dumitrascu DL. Polycystic ovary syndrome: the potential role of probiotic supplementation. Minerva Med 2019;110:1-2.

65. Venkataraman R, Juwal J, Princy J. The effect of probietics on glycenic index. Panminerva Med 2018;60:234-5.

66. Caviglia GP, Rosso C, Ribaldone DG, Dughera F, Fagoonee S, Astegiano M, Pellicano R. Physiopathology of intestinal barrier and the role of zonuitin. Minerva

Biotecnol 2019; 31:83-92. 
Page 16 of 16

1
2
3
4
5
6
7
8
9
10
11
12
13
14
15
16
17
18
19
20
21
22
23
24
25
26
27
28
29
30
31
32
33
34
35
36
37
38
39
40
41
42
43
44
45
46
47
48
49
50
51
52
53
54
55

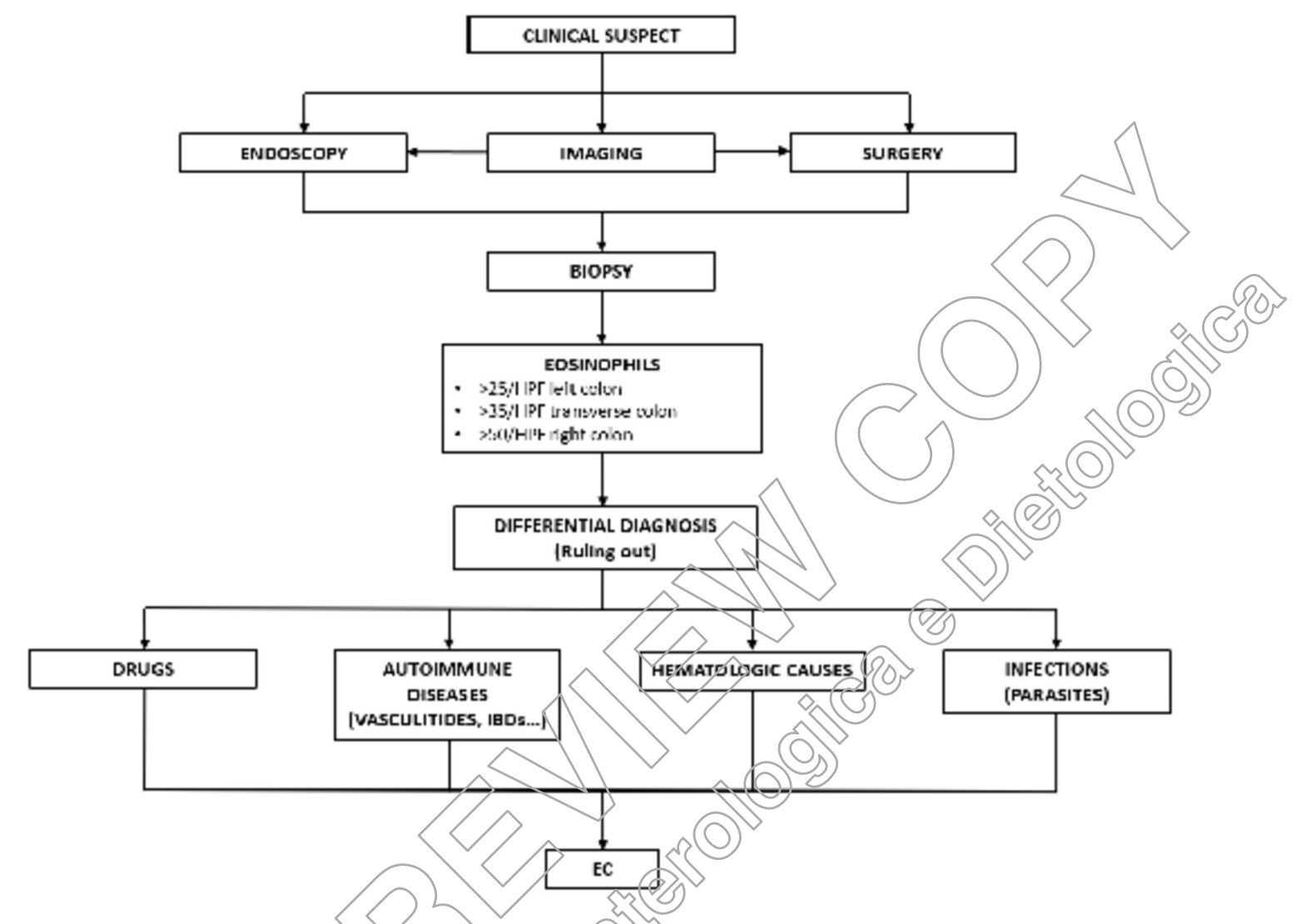

Figure 1. Diagnostic flow chart for the diagnosig or eosinophilic colitis. 